\title{
Development of Future Teachers` Professional Thinking by Means of Task Approach to Organization of Educational Process
}

\author{
Vyshkivska Vanda, \\ Ph.D., Associate Professor \\ Dragomanov National Pedagogical University (Ukraine Kyiv) \\ Kushniruk Svitlana \\ Ph.D., Associate Professor \\ Dragomanov National Pedagogical University (Ukraine Kyiv)
}

\begin{abstract}
The importance of the problem of developing the future teachers' professional thinking as a condition for their effective pedagogical activity is actualized in the article; different approaches of scientists to its interpretation are analyzed. Professional pedagogical thinking is interpreted as a necessary basis for providing future teachers with research skills, developing their pedagogical intuition and key operations, procedures of scientific thinking, forming professional reflection skills. The task approach to the organization of the educational process is such that it involves the introduction into the content of training programs for professionals of applied nature, which allow first to mentally construct different options for solving practical problems of different levels of complexity, to predict their effectiveness, and only then to design the plane of their application in practice, to reflect.
\end{abstract}

Keywords: professional pedagogical activity, thinking, professional pedagogical thinking, pedagogical tasks, task approach.

Сучасній історичній епосі притаманна особлива модель освіти, орієнтована на творчу ініціативу, самостійність, конкурентоспроможність майбутніх фахівців. Творчий потенціал вчителя залежить від рівня сформованості його професійного мислення, яке, в свою чергу, ініціює рефлексивну діяльність, що дає йому можливість стати професійно активним педагогом, здатним до самостійної інноваційної діяльності, i, як результат, - бути затребуваним i конкурентоспроможним.

У системі шкільної освіти відбулися серйозні зміни: диверсифікація, збагачення шкільної практики новими освітніми технологіями, формами навчання, можливістю самостійно вибирати навчально-методичну базу. Підвищення теоретичного рівня змісту навчальних дисциплін призвело до загострення протиріч між загальними цілями освіти і реальними можливостями майбутніх учителів 
вирішувати практичні завдання (нерідко має місце невміння молодих фахівців проявляти самостійність і творчо застосовувати теоретичні знання, набуті у вузі, в шкільній практиці). А сьогодні необхідний вчитель, який володіє сучасною методикою викладання предметів 3 метою формування в учнів ключових компетенцій, готовності до здійснення самостійної пізнавальної діяльності (освітньої компетенції, яка передбачає накопичення інтегрованих знань i їх застосування на практиці).

Відтак, випереджальний розвиток педагогічної освіти обумовлює необхідність розвитку у майбутнього фахівця професійного мислення, здатності оперативно реагувати на різноманітні ситуації в освітньому процесі.

Аналіз останніх досліджень. У наукових дослідженнях професійне мислення вчителя розглядається в трьох аспектах: гносеологічному (О.А. Абдулліна, А.І. Піскунов), діяльнісному (А.К. Маркова, В.А. Сластьонін), творчому (Ю.Н. Кулюткін, М.М. Кашапов та ін.). При цьому автори розглядають його як особливий склад розуму, що володіє рядом ознак, якостей і властивостей, що дозволяють говорити про педагогічне «бачення» світу (В.Е. Тамарін, Д.С. Яковлева); як «системне бачення педагогічного процесу» (Е.П. Нечитайлова); як готовність вчителя до розв'язання різноманітних педагогічних ситуацій (Л.В. Нікітенкова); як здатність застосовувати теоретичні положення педагогіки, психології та методики до конкретних педагогічним ситуацій в поєднанні з умінням «бачити» в конкретному явищі його загальну педагогічну сутність (Л.П. Маслова); як спеціальну сукупність особливостей, властивих практичному мисленню (Е.К. Осіпова).

Деякі аспекти розвитку професійного мислення через розв'язання ряду педагогічних завдань представлені в працях Л.Ф.Спіріна, М.А. Степінського, М.А. Фрумкіна та інші.

Однак формування професійного мислення в період навчання в педагогічному вузі у студентів і сьогодні відбувається не цілеспрямовано і не належним чином науково-організовано. Більш того, згідно з дослідженнями вчених (О.А. Абдулліна, Ю.Н. Кулюткін, М.М. Кашапов і ін.), професійне мислення більшості вчителів є далеко не творчим, рясніє стереотипами і методичними штампами. А тому 
необхідною є систематична спеціальна робота 3 його формування 3 використанням відповідного змісту, форм і методів.

Мета статті - на теоретичному рівні дослідити можливість вирішення педагогічної багатокомпонентної проблеми формування у майбутніх учителів професійного мислення з урахуванням основних факторів, що визначають розвиток освіти сьогодні (у період іiі модернізації), засобами задачного підходу.

\section{Виклад основного матеріалу.}

Деякі вчені (В.І. Загвязінський, Ю.Н. Кулюткін, Н.І. Мешков, Е.К. Осіпова, O.I. Чемоданова і ін.) відзначають, що творчий потенціал вчителя, впершу чергу, залежить від рівня сформованості професійного мислення і потреби у творчій діяльності. Д.В. Вількеев, В.І. Загвязінський, Н.А. Половнікова пов'язують його формування 3 вирішенням наступних конкретних завдань: 3 формуванням логічної культури мислення у студентів; з озброєнням майбутніх педагогів професійними дослідницькими вміннями i навичками; 3 навчанням переносу психологічних i педагогічних теорій, категорій, принципів і законів в конкретні педагогічні ситуації; з розвитком у студентів педагогічної інтуїції; з вихованням у майбутніх учителів і вихователів основ діалектичного мислення; 3 навчанням студентів методам та процедурам наукового мислення, з вихованням здатності до професійної рефлексії, 3 навчанням умінню вести уявний діалог інтелектуального спілкування з учнями; 3 формуванням у студентів предметного наукового мислення в сфері спеціалізації.

Ю.Н. Кулюткін, вказуючи на той факт, що саме мислення дозволяє організовувати та осмислювати інформацію, регулювати внутрішні та зовнішні аспекти діяльності педагога, до важливих якостей педагогічного мислення відносить кмітливість, діалогічність, аналітичність, технологічність, які забезпечують здатність педагога оперативно усвідомлювати та вирішувати завдання; мислити послідовно, формулювати помірковані, доказові умовисновки; детально аналізувати факти та явища, проектувати і переносити задум у площину педагогічної діяльності [9].

Г.С. Костюк, своєю чергою, наголошував, що розвиток мислення має неабияке значення в загальному процесі формування особистості, піi розумових властивостей. Саме розвиток мислення свідчить про здатність особистості 
орієнтуватися в різних складних ситуаціях, передбачати хід подій і результати своїх власних дій, панувати над обставинами і над собою [7].

Відтак, проблема розвитку професійного мислення майбутнього вчителя пов'язана з роботами з загальної теорії мислення і грунтується на дослідженнях особливостей практичного мислення. Поняття «професійне мислення» використовується у науковій літературі в двох аспектах: коли мають на меті підкреслити високий професійно-кваліфікаційний рівень спеціаліста (якісний аспект) та коли акцентують на особливостях мислення, обумовлених характером професійної діяльності (предметний аспект).

С.Л. Рубінштейном були виділені деякі характеристики професійного мислення: витончена спостережливість, вміння використовувати для вирішення завдання особливе i одиничне в даній проблемній ситуації, уміння швидко переходити від мислення до дії і навпаки [10].

В.А. Сластьонін обгрунтовує думку про те, що специфіка педагогічного мислення визначається, 3 одного боку, особливостями мисленнєвої діяльності педагога, професійною спрямованістю пізнавальних процесів, а 3 іншого конструктивно-перетворювальними особливостями, осмисленням кожної навчальновиховної ситуації, оперативним вибором і реалізацією оптимального варіанту іiі вирішення [13].

Т. Гура визначає професійне мислення фахівця як надскладний, інтегративний, поліпроцесуальний i полісистемний феномен; особливий вид мислення, що забезпечує вирішення фахівцем проблем його професійної діяльності і професійного розвитку, функціонує на предметно- орієнтованому, діяльнісноорієнтованому та методологічному рівнях завдяки різнорівневій рефлексії [4]. Науковець також наголошує, що структура професійного мислення фахівця зумовлена особливостями його професійної діяльності та професійного становлення, має багатоплощинну i багатокомпонентну єдність процесуальних i змістових складових. Розпочинається ж воно 3 проблематизації стимульної ситуації, що знаменує умовний початок мисленнєвого пошуку [4].

Визначаючи професійно-педагогічне мислення як здатність до прогнозування, вміння поєднувати теоретичний аналіз і практичне мислення, В.В.Краєвський 
досліджує його в контексті конструктивно-діяльнісного підходу та методології культури, що актуалізує необхідність сформованості у педагога методологічної рефлексії, здатності до наукового обгрунтування, критичного мислення, творчого застосування певних концепцій, форм, методів пізнання, управлінських умінь тощо [8].

Розділяємо думку А. Орлова, який педагогічне мислення розглядає як здатність учителя аналізувати педагогічні ситуації, виокремлювати і вирішувати професійно-педагогічні завдання [10]

Розглянемо детальніше такий засіб розвитку педагогічного мислення, як навчальні задачі (завдання, ситуації). О.А. Дубасенюк визначає останні як спеціально відібрані і складені на основі типових педагогічних ситуацій, що виникають у реальній педагогічній дійсності і які вимагають від майбутніх педагогів застосування набутих психолого-педагогічних знань, оволодіння комплексом педагогічних умінь та навичок, урахування соціального замовлення суспільства, сучасних методологічних підходів, концептуальних ідей, гнучких інноваційних засобів та методів 3 метою отримання продуктивного результату у вигляді позитивних новоутворень в особистісній сфері та діяльності учня і такі, які сприяють зростанню особистості i викликають у неї потребу у саморозвитку та самовдосконаленню у майбутньому та орієнтують на досягнення успіху у подальшій професійно-педагогічній діяльності [5].

Відповідно сутність задачного підходу можна визначити як можливість «побудувати навчальне пізнання особистості як систему задач та розробити алгоритм їх розв'язання $з$ метою допомогти студентам усвідомити проблемність певних ситуацій, знайти форми та методи їх аналізу та розв'язання у процесі підготовки майбутнього фахівця у закладах вищої освіти» [6].

C.В. Сапожніков зауважує про те, що задачний підхід до навчання передбачає уведення до змісту навчальної інформації таких завдань, які активізують мисленнєві процеси студентів, закріплюють у них вміння оперувати теоретичними знаннями у практичних ситуаціях, користуватися ними при вирішенні навчальних завдань, осмислювати і бачити їх прикладний характер у професійній діяльності. Педагогічне ж завдання є одним з інструментів перетворення нових знань на елемент практики, 
найпростішою моделлю якої вони $є$. Засвоюючи певні поняття, теоретичні положення, які пропонуються студентам у вигляді мисленнєвого завдання, студенти відчувають потребу в дії [12].

У методичній підготовці майбутніх учителів у закладі вищої освіти сучасні дослідники пропонують орієнтуватися саме на професійні задачі (проектування, реалізація, аналіз) і відповідні їм функціональні одиниці діяльності. Саме тому задачі і вправи, що відповідають різним рівням рефлексії, включають визначення параметрів навчальної ситуації, аналіз дій учителя й учнів, визначення характеру й причин прояву труднощів, аналіз емоційного стану вчителя й учнів у конкретній ситуації, виділення основних і другорядних факторів, що впливають на динаміку ситуації, пошук альтернативних рішень у даній ситуації, моделювання нової навчальної ситуації, застосування методу аналізу (самоаналізу) [14].

Висновок. Таким чином, професійне педагогічне мислення - це розвинена здатність використовувати прийняті саме в даній професійній області прийоми вирішення проблемних завдань, способи аналізу проблеминх педагогічних ситуацій, прийняття професійних рішень. Задачний підхід до організації освітнього процесу у вищому педагогічному навчальному закладі забезпечує: варіативне відтворення навчального матеріалу з постановкою різноманітних цілей, застосування засобів використання знань у подібних і творчих ситуаціях, систематизацію, самостійний пошук доказів та відповідей на поставлені питання. Відтак, підготовка сучасного вчителя має бути спрямована на формування творчої ерудованої особистості фахівця, що володіє комплексом універсальних знань, професійно спрямованим мисленням, розвиненою педагогічної рефлексією, самосвідомістю, нарешті, громадянина, який чітко усвідомлює відповідальність за свої дії, наслідки яких проектуються не тільки в сьогодення, а й у майбутнє.

Перспективи подальших досліджень пов’язані 3 визначенням особливостей розвитку професійного мислення у майбутніх учителів гуманітарного профілю.

\section{References}

1. Vyshkivska V.B. Rozvytok profesiinoi kompetentnosti maibutnikh fakhivtsiv shliakhom pedahohichnoho proektuvannia kulturno-osvitnoho seredovyshcha zakladiv vyshchoi osvity [Development of professional competence of future specialists through 
pedagogical designing of cultural and educational environment of higher education institutions] // Estetyka i etyka pedahohichnoi dii: zb.nauk.prats / In-t ped.osvity i osvity doroslykh NAPN Ukrainy.- Poltava, 2018. - S. 172-181.

2. Vyshkivska V.B., Kushniruk S.A. Do problemy formuvannia profesiinoi kompetentnosti vchytelia Novoi ukrainskoi shkoly. [To the problem of formation of professional competence of the teacher of the New Ukrainian school] Naukovyi chasopys Natsionalnoho pedahohichnoho universytetu imeni M.P. Drahomanova. Seriia №5. Pedahohichni nauky: realii ta perspektyvy. Vypusk 64. Kyiv: Vyd-vo NPU imeni M.P. Drahomanova. 2018. S. 44-48.

3. Vyshkivska V.B. Modeliuvannia osvitnoho seredovyshcha yak umova vdoskonalennia profesiinoi pidhotovky fakhivtsiv [Modeling the educational environment as a condition for improving the professional training of specialists] // Materialy naukovoi konferentsii vykladachiv kafedry teorii ta istoriipedahohiky / Za nauk. red. L.P. Vovk, V.B. Vyshkivskoi. K.: Vyd-vo NPU imeni M.P.Drahomanova, 2018. S. 95-103.

4. Hura T. Profesiine myslennia: mekhanizm uspishnoi/nevdaloi sotsializatsii fakhivtsia [Professional Thinking: The Mechanism of Successful / Unsuccessful Socialization of the Specialist] //Visnyk Kyivskoho Natsionalnoho universytetu imeni Tarasa Shevchenka. №1 (3). 2015. S. 26-29

5. Dubaseniuk O.A. Realizatsiia zadachnoho pidkhodu u profesiinii pidhotovtsi maibutnoho vchytelia [Implementation of the task approach in the future teacher's professional training] // Novi tekhnolohii navchannia: Materialy mizhnarodnoi konferentsii "Dukhovno-moralne vykhovannia i profesionalizatsiia: vyklyky KhKhI st. ] // № 66. Ch. 1: Instytut innovatsiinykh tekhnolohii i zmistu osvity Ministerstva osvity i nauky Ukrainy, Akademiia mizhnarodnoho spivrobitnytstva z kreaktyvnoi pedahohiky. Kyiv-Vinnytsia, 2010. S. 159-164

6. Zhelanova V.V. Kontekstne navchannia maibutnoho vykladacha pochatkovykh klasiv: teoriia i tekhnolohiia: monohrafiia. [Contextual education of the future elementary school teacher: theory and technology: monograph] Luhansk: LNU imeni Tarasa Shevchenka, 2013. 484 s.

7. Kostiuk H.S. Psykholohiia. Pidruchnyk dlia pedahohichnykh vuziv [Psychology. Textbook for teachers] / za redaktsiieiu prof. H.S. Kostiuka. K.: Radianska shkola. 1961. S. 257.

8. Kraevskyi V.V. Kontseptualnost kursa pedahohyky kak uslovyia formyrovanyia u budushchykh uchytelei konstruktyvno- deiatelnostnoi pozytsyy [Conceptualisation of the course of pedagogy as a condition of formation of constructive-activity position in future teachers] // Pedahohyka kak nauka y uchebnui predmet. Tula: Yzd-vo THPU, 2000. Ch.1. 217 s. S.16.

9. Kuliutkyn Yu.N. Yndyvydualnble razlychyia v mblslytelnoi deiatelnosty vzroslblkh uchashchykhsia. [Individual differences in the thinking activity of adult learners] M.: Pedahohyka, 1971. $111 \mathrm{~s}$.

10. Orlov A. A. Professyonalnoe myshlenye uchytelia kak tsennost [Teacher's professional thinking as a value ] //Pedahohyka. 1995. № 6. S. 63-68. 
11. Rubynshtein S.L. O myshlenyy y putiakh eho yssledovanyia. [About thinking and ways of its research.] M.: Nauka, 1958. 220 s.

12. Sapozhnykov S.V. Naukovo-praktychni pidkhody do orhanizatsii navchalnoho protsesu $v$ pedahohichnykh universytetakh $i$ koledzhakh krain chornomorskoho rehionu [Scientific and practical approaches to the organization of educational process in the pedagogical universities and colleges of the Black Sea region] // Pedahohichni nauky. 2014. № 2 (8). S. 115-121.

13. Slastenyn V.A. Metodolohycheskaia kultura uchytelia [Methodological teacher culture] /V.A. Slastenyn, V.E. Tamaryn // Sovetskaia pedahohyka. 1990. №7. S. 82-88.

14. Solovova E.N. Metodycheskaia podhotovka y perepodhotovka uchytelia ynostrannoho yazyka: yntehratyvno-refleksyvnbil podkhod: monohrafyia. [Methodical preparation and retraining of a foreign language teacher: an integrative-reflexive approach: a monograph] M.: HLOSSA-PRESS, 2004. 336 s.

15. Kushniruk S.A. Formation of readiness for research activity of students in the process of general-pedagogical preparation//Science and practice: Collection of scientific articles. Thorpe Bowker. Melbourne, Australia, 2016. P. 262-267.

16. Kushniruk S.A. Normative and legal frameworks of students' scientific and research activity in pedagogical universities of Ukraine(the $20^{\text {th }}-$ beginning of the $21 \mathrm{st}$ century) // Perspective directions of scientific researches: Collection of scientific articles. Agenda Publishing House, Coventry, United Kingdom, 2016. P. 302-305.

\section{Translation of the Title, Abstract and References to the Author's Language}

\section{УДК 378.091.3:159.955:37091.2}

\section{Вишківська В.Б., Кушнірук С.А. Розвиток професійного мислення майбутніх учителів засобами задачного підходу до організації освітнього процесу.}

У статті актуалізується значущість проблеми розвитку професійного мислення майбутніх учителів як концептуально важливої умови здійснення ними результативної педагогічної діяльності; аналізуються різні підходи науковців до його тлумачення. Професійне педагогічне мислення трактується як необхідна основа озброєнням майбутніх педагогів дослідницькими вміннями, розвитку у них педагогічної інтуїції та ключових операцій i процедур наукового мислення, формуванням навичок професійної рефлексії. Задачний підхід до організації освітнього процесу є таким, що передбачає введення до змісту програм підготовки фахівців педагогічних завдань прикладного характеру різного рівня складності, які дозволяють спочатку мисленнєво конструювати різні варіанти їх розв'язання, прогнозувати результативність, і тільки після цього проектувати площину застосування у практичній діяльності, здійснювати рефлексію

Ключові слова: професійна педагогічна діяльність, мислення, професійне педагогічне мислення, педагогічні задачі, задачний підхід 


\section{Література}

1. Вишківська В.Б. Розвиток професійної компетентності майбутніх фахівців шляхом педагогічного проектування культурно-освітнього середовища закладів вищої освіти// Естетика і етика педагогічної дії: зб.наук.праць / Ін-т пед.освіти і освіти дорослих НАПН України. Полтава, 2018. С. 172-181

2. Вишківська В.Б., Кушнірук С.А. До проблеми формування професійної компетентності вчителя Нової української школи. Науковий часопис Наиіонального педагогічного університету імені М.П.Драгоманова. Серія №5. Педагогічні науки: реалії та перспективи. Випуск 64. Київ: Вид-во НПУ імені М.П. Драгоманова. 2018. C. 44-48.

3. Вишківська В.Б. Моделювання освітнього середовища як умова вдосконалення професійної підготовки фахівців // Матеріали наукової конференції викладачів кафедри теорії та історіїпедагогіки / За наук. ред. Л.П. Вовк, В.Б. Вишківської. К.: Вид-во НПУ імені М.П.Драгоманова, 2018. С. 95-103.

4. Гура Т. Професійне мислення: механізм успішної/невдалої соціалізації фахівця //Вісник Київського Національного університету імені Тараса Шевченка. №1 (3). 2015. C 26-29

5. Дубасенюк О.А. Реалізація задачного підходу у професійній підготовці майбутнього вчителя // Нові технології навчання: Матеріали міжнародної конференції "Духовно-моральне виховання і професіоналізація: виклики XXI ст.] // № 66. Ч. 1: Інститут інноваційних технологій і змісту освіти Міністерства освіти i науки України, Академія міжнародного співробітництва з креактивної педагогіки. Київ-Вінниця, 2010. С. 159-164.

6. Желанова В.В. Контекстне навчання майбутнього викладача початкових класів: теорія і технологія: монографія. Луганськ: ЛНУ імені Тараса Шевченка, 2013. 484 с.

7. Костюк Г.С. Психологія. Підручник для педагогічних вузів / за редакцією проф. Г.С. Костюка. К.: Радянська школа. 1961. С. 257.

8. Краевский В.В. Концептуальность курса педагогики как условия формирования у будущих учителей конструктивно- деятельностной позиции / В. В. Краевский // Педагогика как наука и учебный предмет. Тула: Изд-во ТГПУ, 2000. Ч.1. 217 с. С.16.

9. Кулюткин Ю.Н. Индивидуальные различия в мыслительной деятельности взрослых учащихся / Ю.Н. Кулюткин, Г.С. Сухобская. М.: Педагогика, 1971. $111 \mathrm{c}$.

10. Орлов А.А. Профессиональное мышление учителя как ценность// Педагогика. 1995. № 6. С. 63-68.

11. Рубинштейн С.Л. О мышлении и путях его исследования. М.: Наука, 1958. $220 \mathrm{c}$.

12. Сапожников С.В. Науково-практичні підходи до організації навчального процесу в педагогічних університетах і коледжах країн чорноморського 
регіону / Вісник Дніпропетровського університету імені Альфреда Нобеля Серія «Педагогіка і психологія» // Педагогічні науки. 2014. № 2 (8). С. 115-121

13. Сластенин В.А. Методологическая культура учителя / В.А. Сластенин, В.Э. Тамарин // Советская педагогика. 1990. №7. С. 82-88.

14. Соловова Е.Н. Методическая подготовка и переподготовка учителя иностранного языка: интегративно-рефлексивный подход: монография. $\mathrm{M}$.: ГЛОССА-ПРЕСС, 2004. $336 \mathrm{c}$.

15. Kushniruk S.A. Formation of readiness for research activity of students in the process of general-pedagogical preparation //Science and practice: Collection of scientific articles. Thorpe Bowker. Melbourne, Australia, 2016. P. 262-267.

16. Kushniruk S.A. Normative and legal frameworks of students' scientific and research activity in pedagogical universities of Ukraine(the $20^{\text {th }}$ - beginning of the $21 \mathrm{st}$ century) // Perspective directions of scientific researches: Collection of scientific articles. Agenda Publishing House, Coventry, United Kingdom, 2016. P. 302-305. 